\title{
Production of Napiergrass as a Bioenergy Feedstock Under Organic Versus Inorganic Fertilization in the Southeast USA
}

\author{
Joseph E. Knoll • William F. Anderson • \\ Ravindra Malik • Robert K. Hubbard • \\ Timothy C. Strickland
}

Published online: 10 April 2013

(C) The Author(s) 2013. This article is published with open access at Springerlink.com

\begin{abstract}
Napiergrass (Pennisetum purpureum Schum.) is a high-yielding perennial biomass crop that is well adapted to the Southeast USA where poultry litter is readily available. This research was conducted to compare biomass production and nutrient utilization of napiergrass fertilized with either poultry litter or inorganic fertilizer. Each spring, approximately $100 \mathrm{~kg} \mathrm{ha}^{-1}$ of $\mathrm{N}, 40 \mathrm{~kg} \mathrm{ha}^{-1} \mathrm{P}$, and $90 \mathrm{~kg} \mathrm{ha}^{-1} \mathrm{~K}$ were applied as poultry litter or equivalent inorganic fertilizer. Biomass was harvested each winter after senescence. For the first 2 years, dry matter yield did not differ among treatments, but in the third and fourth years, yields declined in all treatments and were lowest in the unfertilized treatment. Biomass $\mathrm{N}$ concentration and $\mathrm{N}$ removal were greatest in the inorganic treatment. In general, $\mathrm{N}$ removal exceeded the amount applied, suggesting that higher application rates may be necessary to maintain yields. Biomass $\mathrm{P}$ concentration and total $\mathrm{P}$ uptake were greatest in the litter fertilized treatment, demonstrating that napiergrass can remove some of the excess $\mathrm{P}$ from applied litter. Soil cores were taken periodically to assess changes in soil properties. After 2 years of production, soil $\mathrm{pH}$ in the surface layer $(0-15 \mathrm{~cm})$ was lower in the inorganic treatment than in the other treatments. After 4 years, total soil $\mathrm{C}$ had increased by an average of $3,180 \mathrm{~kg} \mathrm{ha}^{-1}$ though fertilizer
\end{abstract}

J. E. Knoll • W. F. Anderson

Crop Genetics and Breeding Research Unit, USDA-ARS, P.O.

Box 748, Tifton, GA 31793, USA

R. Malik

College of Sciences \& Health Professions, Department of Natural

Sciences, Albany State University, Albany, GA 31705, USA

R. K. Hubbard $\cdot$ T. C. Strickland $(\bowtie)$

Southeast Watershed Research Laboratory, USDA-ARS, P.O. Box

748, Tifton, GA 31793, USA

e-mail: Tim.Strickland@ars.usda.gov treatments did not differ. Yield declined in all treatments after 4 years and $\mathrm{N}$ supplementation is recommended for production in upland fields.

Keywords Poultry litter $\cdot$ Nitrogen $\cdot$ Phosphorus $\cdot$ Potassium · Biomass crops · Soil carbon · GRACEnet · LTAR

\section{Introduction}

Napiergrass (Pennisetum purpureum Schum.), also known as elephantgrass, is a large perennial grass native to tropical sub-Saharan Africa. Because it is a $\mathrm{C}_{4}$ species, napiergrass is capable of producing large quantities of biomass in areas with long warm growing seasons and is being studied as a feedstock for the emerging bioenergy industry in the Southeast USA. Annual DMY over $24 \mathrm{Mg} \mathrm{ha}^{-1}$ has been reported in Florida [1,2] and Georgia [3]. Research is needed to determine the most efficient, economical, and sustainable means of producing biomass from this crop. Because the per-unit value of raw lignocellulosic biomass is expected to be quite low, production systems requiring minimal inputs of fertilizer and irrigation are preferred.

Like all grasses, napiergrass requires a source of $\mathrm{N}$ fertilizer for optimal growth, but inorganic $\mathrm{N}$ fertilizers are relatively expensive. Castillo et al. [3] found that napiergrass annual DMY declined 4.1 Mg ha ${ }^{-1}$ when N (350 kg ha ${ }^{-1}$ year $^{-1}$ ) was supplied as municipal biosolids as compared to inorganic fertilizer $\left(\mathrm{NH}_{4} \mathrm{NO}_{3}\right)$. Poultry (Gallus gallus) litter, consisting of manure, feathers, and wood shavings, is an inexpensive fertilizer source that is plentiful in the Southeast. Application of poultry litter may provide additional benefits, such as increasing soil $\mathrm{C}$ and improving soil structure and water-holding capacity [4-6]. Previous studies have also demonstrated the 
soil $\mathrm{C}$ sequestering ability of perennial grasses such as Andropogon gayanus and Brachiaria humidicola [7], tall fescue (Lolium arundinaceum Schreb) [8], and switchgrass (Panicum virgatum L.) [9]. Practices that sequester $\mathrm{C}$ in the soil should be incorporated into biomass production systems, as the Energy Independence and Security Act (EISA) of 2007 [10] requires that each category of renewable fuels emits fewer greenhouse gases than the petroleum fuel it replaces. The objectives of this research were to compare the effects of inorganic fertilizer versus poultry litter on biomass yield and nutrient composition of napiergrass and on soil $\mathrm{C}$ and $\mathrm{N}$ balances in a low-input production system.

\section{Materials and Methods}

\section{Experimental Design}

The research site was located near Ty Ty, GA $\left(31^{\circ} 30^{\prime} 41.62^{\prime \prime}\right.$ $\mathrm{N}$; $83^{\circ} 38^{\prime} 52.12^{\prime \prime} \mathrm{W}$ ) on a Tifton loamy sand (fine-loamy, kaolinitic, thermic Plinthic Kandiudult) that had been planted to cotton in the preceding 9 years. Fertilization during the preceding period was 91,10 , and $40 \mathrm{~kg} \mathrm{ha}^{-1}$ year $^{-1}$ of $\mathrm{N}, \mathrm{P}$, and K, respectively. On 13 September 2006, stem cuttings (approximately $30 \mathrm{~cm}$ ) of napiergrass cultivar Merkeron [11] were planted $0.9 \mathrm{~m}$ apart in rows $0.9 \mathrm{~m}$ apart in plots $22.8 \mathrm{~m}$ long by $10.9 \mathrm{~m}$ wide, with a slope of approximately $2 \%$. Some replanting was necessary on 3 May 2007 to establish an even stand.

The experimental design was a randomized complete block with three blocks. Three fertilizer treatments were applied: poultry litter $\left(3,260 \mathrm{~kg} \mathrm{ha}^{-1}\right.$ year $\left.{ }^{-1}\right)$, inorganic fertilizer, or unfertilized control. Both the litter and inorganic fertilizers were surface applied each spring. In 2007, a commercial 10-10-10 blend was used for the inorganic treatment. In subsequent years, the inorganic $\mathrm{N}$ source was ammonium nitrate $\left(\mathrm{NH}_{4} \mathrm{NO}_{3}\right)$ and the inorganic sources of $\mathrm{P}$ and $\mathrm{K}$ were triple superphosphate $\left[\mathrm{Ca}\left(\mathrm{H}_{2} \mathrm{PO}_{4}\right)_{2}\right]$ and potassium chloride $(\mathrm{KCl})$, respectively. The composition of nutrients in the litter varied from year to year, thus the amounts of applied nutrients also varied. The target fertilization rates were 100,40 , and $90 \mathrm{~kg} \mathrm{ha}{ }^{-1}$ year $^{-1}$ of $\mathrm{N}, \mathrm{P}$, and $\mathrm{K}$, respectively. Actual rates varied by poultry litter source and are presented in Table 1.

Plots were separated by rigid plastic dividers to prevent runoff between plots. Other than at planting, no supplemental irrigation was applied, and all aboveground biomass was removed from the plots after harvest. Weeds were controlled by application of $4.7 \mathrm{~L} \mathrm{ha}^{-1}$ each of 2,4-dichlorophenoxyacetic acid (2,4-D) and Surflan (United Phosphorus, Inc., Trenton, NJ, USA) in mid-March in 2007 and 2008. Afterward, weeds were controlled by spot spraying with glyphosate as needed.

\section{Evaluation of Biomass Production}

Because of inconsistent stand establishment in the first growing season, the 2007 biomass yield (8 January 2008) was measured by harvesting and weighing the aboveground biomass of ten randomly chosen plants from each plot. From each plant, two individual stalks were then divided into leaves and stem, weighed fresh, dried to completion at $60{ }^{\circ} \mathrm{C}$ in an oven, and then weighed again to determine moisture concentration and leaf to stem ratios. After weighing, dried samples were ground in a Wiley mill to pass a 2-mm screen and were stored for later analyses. Plots were replanted in 2007 to fill in gaps, and three separate sections $\left(9.3 \mathrm{~m}^{2}\right.$ each) were harvested in subsequent years (8 January 2009, 8 February 2010, and 24 January 2011) from each plot and the total fresh biomass was weighed. A bulk chopped sample was taken from each section for determination of moisture concentration as described above. These samples were also ground to pass $2 \mathrm{~mm}$ for further analyses, and were not separated into leaves and stems.

\section{Biomass Nutrient Analyses}

Total $\mathrm{N}$ and $\mathrm{C}$ concentrations in the biomass were measured by dry combustion in a Vario EL-III Universal CHN Elemental Analyzer (Elementar Analysensysteme, Hanau, Germany) using approximately $5 \mathrm{mg}$ dried, ground tissue. Biomass $\mathrm{K}$ and $\mathrm{P}$ concentrations were measured at the University of Georgia Agricultural and Environmental Services Laboratories (http://aesl.ces.uga.edu/) by inductively coupled plasma spectrometry. Nutrient removal was calculated by multiplying biomass nutrient concentration by DMY.

\section{Collection and Analysis of Soil and Roots}

Soil cores (58 mm diameter) were collected each spring (5 June 2007, 22 April 2008, 29 April 2009, and 29 March 2011) prior to fertilizer application using a hydraulic tractormounted soil probe (Giddings Machine Co., Ft. Collins, CO, USA). Each core was sampled adjacent to the crown of an individual plant to a depth of approximately $75 \mathrm{~cm}$ and was sub-sampled in 15-cm increments for further analyses. Because of the large number of samples to be processed, only alternating increments $(0-15,30-45$, and 60-75 cm) were analyzed. Soil samples were sieved $(2 \mathrm{~mm})$ and subsampled ( $200 \mathrm{~g}$ fresh weight) for determination of chloroform-extractable $\mathrm{C}$ and $\mathrm{N}$ (extractable $\mathrm{C}$ and $\mathrm{N}$ ). Three 50-g subsamples from each $15-\mathrm{cm}$ increment were treated with $1.0 \mathrm{~mL}$ of ethanol-free chloroform and maintained under vacuum for 7 days at room temperature. Following fumigation, samples were extracted with $0.5 \mathrm{M}$ 
Table 1 Fertilizer nutrients applied $\left(\mathrm{kg} \mathrm{ha}^{-1}\right)$ each year to napiergrass plots prior to spring growth

\begin{tabular}{|c|c|c|c|c|c|c|c|c|}
\hline & \multicolumn{2}{|l|}{$\mathrm{N}$} & \multicolumn{2}{|l|}{$\mathrm{P}$} & \multicolumn{2}{|l|}{ K } & \multirow{2}{*}{$\begin{array}{l}\mathrm{Ca} \\
\text { Litter }\end{array}$} & \multirow[t]{2}{*}{ Litter applied } \\
\hline & Litter & Inorg & Litter & Inorg & Litter & Inorg & & \\
\hline 2007 & 101 & 90 & 41 & 90 & 85 & 90 & 79 & 3,255 \\
\hline 2008 & 99 & 99 & 16 & 37 & 32 & 39 & 29 & 3,255 \\
\hline 2009 & 99 & 99 & 39 & 37 & 103 & 39 & 75 & 3,255 \\
\hline 2010 & 100 & 100 & 45 & 46 & 89 & 90 & 60 & 3,255 \\
\hline Total & 399 & 388 & 141 & 210 & 309 & 258 & 243 & 13,020 \\
\hline
\end{tabular}

$\mathrm{K}_{2} \mathrm{SO}_{4}$, and filtrates (Whatman GF-F) were analyzed for total $\mathrm{C}$ and $\mathrm{N}$ on a Shimadzu TOC-VCPN analyzer with ASI-V autosampler and a TNM-1 Nitrogen module. The water concentration of the remaining soil was measured gravimetrically by oven-drying $\left(105^{\circ} \mathrm{C}\right)$ and soil bulk density was taken as the mass of material $<2 \mathrm{~mm}$ per core volume $\left(402.7 \mathrm{~cm}^{3}\right)$. Total $\mathrm{C}$ and $\mathrm{N}$ in the soil samples were measured by dry combustion on a Vario EL-III Universal CHN Elemental Analyzer using approximately $50 \mathrm{mg}$ dry soil that had been ground in a roller mill. All calculations are adjusted for stone content ( $>20 \%$ in some samples) and soil bulk density.

Soil cores were collected on 29 April 2009 and 29 September 2010 to collect and isolate roots. Roots were separated from soil by hand, dried to completion at $65^{\circ} \mathrm{C}$, and weighed to estimate root biomass. Carbon and $\mathrm{N}$ concentrations of roots were determined as for shoot biomass. Soil pH was measured on 2009 samples by electrode after mixing $10 \mathrm{~g}$ dry soil with $10 \mathrm{ml}$ deionized water for $10 \mathrm{~min}$. All depth increments of the 2010 cores were analyzed.

\section{Data Analysis}

Data were analyzed using the GLIMMIX procedure in SAS v. 9.2 (SAS Institute, Cary, NC, USA). In this analysis, year was treated as a fixed factor due to the perennial nature of the crop and presumed soil nutrient depletion over time. Repeated measures on the same plots were incorporated into the model using the SUBJECT option within the RANDOM statement. The year-by-treatment interaction was also included in the model. Some data, for example nutrient removals, were analyzed using the DIST $=$ LOGNORMAL option to correct for overdispersion. Simple effect LS means comparisons were calculated using the SLICEDIFF option. Tukey's HSD test was used for all LS means comparisons. Unless otherwise stated, statistical significance is declared at a probability level of $\alpha=0.05$. Multiple regressions and $95 \%$ confidence intervals for extractable soil $\mathrm{C}$ and $\mathrm{N}$ were developed using SigmaPlot 11.0 (Systat Software, Inc., Point Richmond, CA, USA). Data was combined for each of the $0-15 \mathrm{~cm}$ and $30-45 \mathrm{~cm}$ depth samples for each study year, and the slope of the regressions between the different years were compared for overlap of the $95 \%$ confidence intervals for each regression. No overlap between these confidence intervals indicated significant difference between the associated slopes.

\section{Results and Discussion}

\section{Biomass Yield and Nutrient Uptake}

While the 2007 biomass yields cannot be statistically compared to those in subsequent years due to the establishment problems identified earlier, DMY among the three treatments did not differ (30.0 $\mathrm{Mg} \mathrm{ha}^{-1}$, Table 2) and were comparable to first-year napiergrass yields reported by Knoll et al. [3] for a similar environment. In 2008, DMY did not differ among treatments with a mean yield of 20.6 $\mathrm{Mg} \mathrm{ha}^{-1}$. In 2009 and 2010, the unfertilized yield was less than the inorganic treatment, but the litter treatment was not significantly different from either of the other treatments. Averaged across all 4 years, DMY between the two fertilized treatments was not different, but both were significantly greater than the unfertilized control. Dry matter yields declined over time in all treatments with the greatest declines in the unfertilized control (Table 2). Declines were not a result of water deficit since rainfall during the 2009 and 2010 growing seasons was greater than in 2007 and 2008 (Fig. 1). There were no indications of stem or leaf disease or insect herbivory during the research period.

Though yield did not differ between treatments in the first 2 years, $\mathrm{N}$ concentration in the harvested biomass was significantly greater in the inorganically fertilized treatment than in the control in the second and third years (Table 2). Biomass $\mathrm{N}$ concentration decreased in all treatments through 2009 and was accompanied by a substantial widening of $\mathrm{C} / \mathrm{N}$ ratio. In general, $\mathrm{N}$ concentrations were higher and $\mathrm{C} / \mathrm{N}$ ratios were more narrow over the 4-year period in the order inorganic $\geq$ litter $\geq$ control, and the difference between inorganic and control treatments was significant (Table 2). Some variation in biomass $\mathrm{N}$ concentration and $\mathrm{C} / \mathrm{N}$ ratio observed between years could be due to air temperature differences preceding harvest. In the period from first freeze of the year until harvest, the temperature was 
Table 2 Biomass dry matter yield and nutrient concentrations $( \pm$ SE) for napiergrass fertilized with inorganic fertilizer, poultry litter, or unfertilized control $^{\mathrm{a}}$

\begin{tabular}{|c|c|c|c|c|c|c|c|c|c|c|}
\hline \multirow[b]{2}{*}{ Treatment } & \multicolumn{10}{|l|}{ Year } \\
\hline & \multicolumn{2}{|l|}{2007} & \multicolumn{2}{|l|}{2008} & \multicolumn{2}{|l|}{2009} & \multicolumn{2}{|l|}{2010} & \multicolumn{2}{|l|}{ 4-year mean } \\
\hline \multicolumn{11}{|c|}{ DMY, Mg ha ${ }^{-1}$} \\
\hline Inorganic & $29.7(1.7)$ & $\mathrm{a}$ & $21.8(1.4)$ & $\mathrm{aA}^{\mathrm{b}}$ & $19.0(1.2)$ & $\mathrm{aB}$ & $12.1(0.6)$ & $\mathrm{aC}$ & $20.7(3.6)$ & $\mathrm{a}$ \\
\hline Litter & $30.9(1.3)$ & $\mathrm{a}$ & $21.7(1.1)$ & $\mathrm{aA}$ & $17.6(1.4)$ & $\mathrm{abB}$ & $8.9(0.5)$ & $\mathrm{abC}$ & $19.8(4.6)$ & $\mathrm{a}$ \\
\hline Control & $29.3(1.2)$ & $\mathrm{a}$ & $18.6(1.1)$ & $\mathrm{aA}$ & $11.9(0.9)$ & $\mathrm{bB}$ & $5.9(0.3)$ & $\mathrm{bC}$ & $16.4(5.0)$ & $\mathrm{b}$ \\
\hline \multicolumn{11}{|c|}{$\mathrm{N}$ concentration, $\mathrm{g} \mathrm{kg}^{-1}$} \\
\hline Inorganic & $9.0(0.3)$ & $\mathrm{aA}$ & $4.9(0.3)$ & $\mathrm{aB}$ & $2.1(0.2)$ & $\mathrm{aC}$ & $3.4(0.3)$ & $\mathrm{aD}$ & $4.9(1.5)$ & a \\
\hline Litter & $7.7(0.3)$ & $\mathrm{aA}$ & $3.8(0.3)$ & $\mathrm{abB}$ & $1.6(0.1)$ & $\mathrm{abC}$ & $3.2(0.2)$ & $\mathrm{aD}$ & $4.1(1.3)$ & $\mathrm{ab}$ \\
\hline Control & $7.2(0.3)$ & $\mathrm{aA}$ & $3.0(0.3)$ & $\mathrm{bB}$ & $1.4(0.2)$ & $\mathrm{bC}$ & $2.9(0.1)$ & $\mathrm{aB}$ & $3.6(1.3)$ & $\mathrm{b}$ \\
\hline \multicolumn{11}{|c|}{$\mathrm{C} / \mathrm{N}$ ratio } \\
\hline Inorganic & $52(2)$ & $\mathrm{aA}$ & $93(8)$ & $\mathrm{bB}$ & $246(21)$ & $\mathrm{bC}$ & $146(11)$ & $\mathrm{aD}$ & $134(42)$ & $\mathrm{b}$ \\
\hline Litter & $63(4)$ & $\mathrm{aA}$ & $126(12)$ & $\mathrm{abB}$ & $328(32)$ & $\mathrm{abC}$ & $147(6)$ & $\mathrm{aD}$ & $166(57)$ & $a b$ \\
\hline Control & $69(4)$ & $\mathrm{aA}$ & $167(15)$ & $\mathrm{aB}$ & $389(38)$ & $\mathrm{aC}$ & $166(7)$ & $\mathrm{aB}$ & $198(68)$ & a \\
\hline \multicolumn{11}{|c|}{$\mathrm{K}$ concentration, $\mathrm{g} \mathrm{kg}^{-1}$} \\
\hline Inorganic & $18.9(1.1)$ & $\mathrm{aA}$ & $14.7(1.0)$ & $\mathrm{aB}$ & $7.4(1.0)$ & $\mathrm{aC}$ & $6.9(1.0)$ & $\mathrm{aC}$ & $12.0(0.8)$ & a \\
\hline Litter & $17.1(1.1)$ & $\mathrm{aA}$ & $14.9(1.0)$ & $\mathrm{aB}$ & $9.7(1.0)$ & $\mathrm{aC}$ & $9.4(1.0)$ & $\mathrm{aD}$ & $12.8(0.8)$ & $\mathrm{a}$ \\
\hline Control & $17.8(1.1)$ & $\mathrm{aA}$ & $12.9(1.0)$ & $\mathrm{aB}$ & $9.0(1.0)$ & $\mathrm{aC}$ & $8.3(1.0)$ & $\mathrm{aD}$ & $12.0(0.8)$ & $\mathrm{a}$ \\
\hline \multicolumn{11}{|c|}{$P$ concentration, $\mathrm{g} \mathrm{kg}^{-1}$} \\
\hline Inorganic & $0.82(0.11)$ & $\mathrm{aA}$ & $1.31(0.09)$ & $\mathrm{bB}$ & $0.73(0.09)$ & $\mathrm{bC}$ & $0.99(0.09)$ & $\mathrm{bD}$ & $0.96(0.06)$ & $\mathrm{b}$ \\
\hline Litter & $1.01(0.11)$ & $\mathrm{aA}$ & $1.69(0.09)$ & $\mathrm{aB}$ & $1.35(0.09)$ & $\mathrm{aABC}$ & $1.55(0.09)$ & $\mathrm{aBC}$ & $1.40(0.06)$ & $\mathrm{a}$ \\
\hline Control & $0.84(0.11)$ & $\mathrm{aAC}$ & $1.19(0.09)$ & $\mathrm{bB}$ & $1.06(0.09)$ & $\mathrm{abA}$ & $1.24(0.09)$ & $\mathrm{abC}$ & $1.08(0.06)$ & $\mathrm{b}$ \\
\hline
\end{tabular}

${ }^{a}$ Treatment means within columns followed by the same lowercase letter are not significantly different $(P \geq 0.05)$

${ }^{\mathrm{b}}$ Year means within a treatment followed by the same uppercase letter are not significantly different $(P \geq 0.10)$

significantly lower in 2009 and 2010 during the 14 days preceding the first freeze, there were two to three times the number of days when the temperature dropped below freezing, and the average minimum temperature was significantly lower than during 2007 and 2008 (Table 3). The retranslocation of nutrients from above- to below-ground biomass of reed canarygrass (Phalaris arundinacea L.) and Miscanthus has been reported after senescence [12, 13],

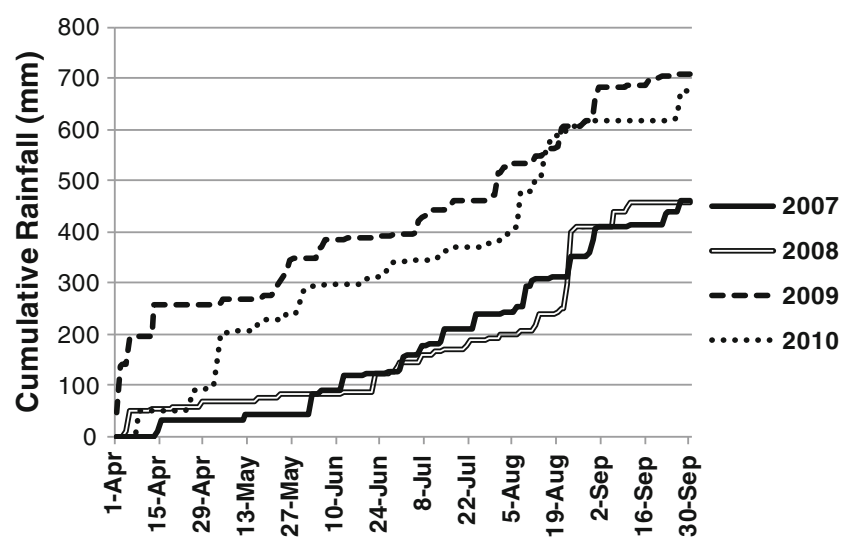

Fig. 1 Growing season precipitation, 2007-2010 and our data suggests a similar response for napiergrass. Potassium concentration in harvested biomass did not differ among treatments in any of the 4 years tested, but declined over time in all treatments (Table 2). In all 4 years, the concentration of $\mathrm{P}$ in napiergrass biomass was greatest in the litter treatment, though the differences among the three treatments were not significant in 2007 (Table 2). Biomass P concentration in the litter treatment was significantly greater than in the inorganic treatment in the succeeding 3 years, but did not differ from the control in the last 2 years. Overall, the 4-year mean P concentration of litter-fertilized biomass was higher than in the inorganic and control treatments. Unlike $\mathrm{N}$ and $\mathrm{K}$, the biomass $\mathrm{P}$ concentration did not decline over time in any of the treatments. The declines over time in biomass N (57 \%-62\%) and K (45\%-64\%) concentrations suggest that deficiencies in both nutrients were likely associated with yield declines, while the increase in $\mathrm{P}$ concentration $(21 \%-53 \%)$ suggests that yield was not P-limited.

Total nutrient removal in biomass was not different among treatments in 2007 for $\mathrm{N}, \mathrm{P}$, or K (Table 4). Biomass N removed in the inorganic treatment was greater than in the unfertilized control for all subsequent years. Biomass N removal for all treatments during the first year $\left(187-234 \mathrm{~kg} \mathrm{ha}^{-1}\right)$ 
Table 3 Association between napiergrass harvest timing and air temperature $\left({ }^{\circ} \mathrm{C}\right)^{\mathrm{a}}$

${ }^{\text {a } Y e a r ~ m e a n s ~ f o l l o w e d ~ b y ~ t h e ~}$ same letter are not significantly different $(P \geq 0.05)$

\begin{tabular}{lllll}
\hline Crop year & 2007 & 2008 & 2009 & 2010 \\
\hline Harvest date & 8-Jan-08 & 8-Jan-09 & 8-Feb-10 & 24-Jan-11 \\
Date of first freeze & 8 -Nov-07 & 19-Nov-08 & 6-Dec-09 & 2-Dec-10 \\
Average minimum temperature & $10.3 \mathrm{a}$ & $8.8 \mathrm{a}$ & $5.8 \mathrm{~b}$ & $7.9 \mathrm{~b}$ \\
$\quad 14$ days preceding first freeze & 63 & 53 & 65 & 54 \\
First freeze to harvest: days & 9 & 8 & 18 & 29 \\
Days below freezing & -5.9 & -2.5 & -6.9 & -6.7 \\
Minimum temperature & $6.2 \mathrm{a}$ & $6.4 \mathrm{a}$ & $3.1 \mathrm{~b}$ & $0.1 \mathrm{c}$ \\
Average minimum temperature & & & & \\
\hline
\end{tabular}

was comparable to the amounts reported by Castillo et al. [2] (162-208 $\left.\mathrm{kg} \mathrm{ha}^{-1}\right)$ in a study comparing inorganic fertilizer to municipal biosolids. Potassium removal was significantly greater in the litter treatment than in the unfertilized control in 2008 and 2009, and in $2010 \mathrm{~K}$ removal was significantly greater in both fertilized treatments than in the control. Biomass $\mathrm{P}$ removal in the litter treatment was higher than from both other treatments in 2008-2010. The difference was significant in all 3 years for the control treatment and in 2009 for the inorganic treatment.

The proportion of nutrients removed at harvest relative to fertilizer addition reinforces the suggestion that nutrient limitations occurred for both $\mathrm{N}$ and $\mathrm{K}$ (Table 4). Biomass $\mathrm{N}$ removal was $213 \%-260 \%$ of added $\mathrm{N}$ in 2007 and dropped to $81 \%-103 \%$ in 2008 and to $27 \%-39 \%$ in 2009. The third-year drop in removal rate below fertilization rate coincided with the first year that DMY in the control treatment was significantly below the fertilized treatments and with the first year that yields dropped significantly in all three treatments (Table 2). Biomass $\mathrm{K}$ removal increased from 2007 to 2008 and then began to decline from 2008 to 2010 (Table 4). The 2010 data showing removal at $91 \%$ $93 \%$ of added $\mathrm{K}$ suggests that the soil $\mathrm{K}$ availability may have been approaching deficit levels. $\mathrm{P}$ removal in biomass never exceeded $39 \mathrm{~kg} \mathrm{ha}^{-1}$ which was at or below the target application rate in all years. The proportion of $\mathrm{P}$ removed in biomass exceeded $100 \%$ of added only in 2008 for the litter treatment. The litter applied during 2008 was very low in $\mathrm{P}$ (16 kg P ha ${ }^{-1}$ ) suggesting that $\mathrm{P}$ demand for napiergrass may fall in the range of $20-40 \mathrm{~kg} \mathrm{ha}^{-1}$ year $^{-1}$. Castillo et al. [2] observed biomass $P$ removal rates at the higher end of this range $\left(36-43 \mathrm{~kg} \mathrm{ha}^{-1}\right)$.

Table 4 Annual removals of N, P, and K in napiergrass biomass treated with inorganic fertilizer, poultry litter, or unfertilized control ${ }^{\mathrm{a}}$

\begin{tabular}{|c|c|c|c|c|c|c|c|c|c|c|}
\hline & $\begin{array}{l}\text { Removed } \\
\left(\mathrm{kg} \mathrm{ha}^{-1}\right)\end{array}$ & $\begin{array}{l}\% \text { of } \\
\text { Added }\end{array}$ & $\begin{array}{l}\text { Removed } \\
\left(\mathrm{kg} \mathrm{ha}^{-1}\right)\end{array}$ & $\begin{array}{l}\% \text { of } \\
\text { Added }\end{array}$ & $\begin{array}{l}\text { Removed } \\
\left(\mathrm{kg} \mathrm{ha}^{-1}\right)\end{array}$ & $\begin{array}{l}\% \text { of } \\
\text { Added }\end{array}$ & $\begin{array}{l}\text { Removed } \\
\left(\mathrm{kg} \mathrm{ha}^{-1}\right)\end{array}$ & $\begin{array}{l}\% \text { of } \\
\text { Added }\end{array}$ & $\begin{array}{l}\text { Removed } \\
\left(\mathrm{kg} \mathrm{ha}^{-1}\right)\end{array}$ & $\begin{array}{l}\% \text { of } \\
\text { Added }\end{array}$ \\
\hline & \multicolumn{2}{|l|}{2007} & \multicolumn{2}{|l|}{2008} & \multicolumn{2}{|l|}{2009} & \multicolumn{2}{|l|}{2010} & \multicolumn{2}{|l|}{ Total } \\
\hline \multicolumn{11}{|c|}{ Nitrogen } \\
\hline Inorganic & $230 \mathrm{a}$ & 260 & $100 \mathrm{a}$ & 103 & $40 \mathrm{a}$ & 39 & $40 \mathrm{a}$ & 40 & $420 \mathrm{a}$ & 107 \\
\hline Litter & $220 \mathrm{a}$ & 213 & $80 \mathrm{ab}$ & 81 & $30 \mathrm{ab}$ & 27 & $30 \mathrm{ab}$ & 28 & $350 \mathrm{ab}$ & 88 \\
\hline Control & $190 \mathrm{a}$ & - & $50 \mathrm{~b}$ & - & $20 b$ & - & $20 \mathrm{~b}$ & - & $270 \mathrm{~b}$ & - \\
\hline $\mathrm{SE}^{\mathrm{b}}$ & 36 & - & 4 & - & 4 & - & 4 & - & 41 & - \\
\hline \multicolumn{11}{|c|}{ Phosphorus } \\
\hline Inorganic & $24 \mathrm{a}$ & 26 & $28 \mathrm{ab}$ & 74 & $13 b$ & 35 & $12 \mathrm{a}$ & 25 & $80 \mathrm{~b}$ & 36 \\
\hline Litter & $29 a$ & 72 & $36 a$ & 223 & $23 a$ & 59 & $14 \mathrm{a}$ & 30 & $100 \mathrm{a}$ & 72 \\
\hline Control & $24 \mathrm{a}$ & - & $21 b$ & - & $12 b$ & - & $7 b$ & - & $60 \mathrm{~b}$ & - \\
\hline SE & 3.0 & - & 2.3 & - & 2.3 & - & 2.3 & - & 6.8 & - \\
\hline \multicolumn{11}{|c|}{ Potassium } \\
\hline Inorganic & $540 \mathrm{a}$ & 601 & $310 \mathrm{ab}$ & 790 & $140 \mathrm{ab}$ & 349 & $80 \mathrm{a}$ & 91 & $1,070 \mathrm{a}$ & 414 \\
\hline Litter & $530 \mathrm{a}$ & 618 & $320 \mathrm{a}$ & 988 & $170 \mathrm{a}$ & 161 & $80 \mathrm{a}$ & 93 & $1,090 \mathrm{a}$ & 353 \\
\hline Control & $520 \mathrm{a}$ & - & $230 \mathrm{~b}$ & - & $100 \mathrm{~b}$ & - & $50 \mathrm{~b}$ & - & $900 \mathrm{~b}$ & - \\
\hline SE & 68 & - & 17 & - & 17 & - & 17 & - & 93 & - \\
\hline
\end{tabular}

${ }^{a}$ Within years, means with the same letter are not significantly different $(P \geq 0.05)$

${ }^{\mathrm{b}} S E$ standard error 
Regression of dry matter yield and $\mathrm{C} / \mathrm{N}$ ratio against $\mathrm{N}$ removal (Fig. 2) demonstrates that napiergrass can maintain high dry matter yields $\left(>20 \mathrm{Mg} \mathrm{ha}^{-1}\right)$ over a considerable range of tissue $\mathrm{C} / \mathrm{N}$ ratios $(\sim 250-400)$. However, if tissue $\mathrm{C} / \mathrm{N}$ ratio dropped below this range, dry matter yield dropped below $20 \mathrm{Mg} \mathrm{ha}^{-1}$ and continued to decline sharply as the tissue $\mathrm{C} / \mathrm{N}$ ratio narrowed. Regression indicated that the amount of $\mathrm{N}$ removed in harvested biomass declined by $55-65 \mathrm{~kg} \mathrm{ha}^{-1}$ year $^{-1}\left(R^{2}, 0.76-0.82\right)$ and was accompanied by a decline in $\mathrm{N}$ fertilizer use efficiency (NUE) of 64$69 \mathrm{~kg} \mathrm{~kg}^{-1} \mathrm{~N}$ in the inorganic and litter fertilized treatments $\left(R^{2}, 0.95-0.98\right)$. The $1: 1$ decline in $\mathrm{N}$ removal/NUE indicates that the level of plant-available $\mathrm{N}$ in the soil must remain well above $100 \mathrm{~kg} \mathrm{ha}^{-1}$ year $^{-1}$, but additional research is needed to determine the most efficient $\mathrm{N}$ fertilization rate for napiergrass. Similar regressions indicate that $\mathrm{K}$ removal declined by $148-155 \mathrm{~kg} \mathrm{ha}^{-1}$ year $^{-1}\left(R^{2}, 0.90-\right.$ $0.96)$ and $\mathrm{P}$ removal by $5-6 \mathrm{~kg} \mathrm{ha}^{-1}$ year $^{-1}\left(R^{2}, 0.68-0.95\right)$.

\section{Estimates of Root Biomass}

In September of 2010, most of the roots were found in the 0-30 cm layer (Table 5), which agrees with previous observations of rooting distribution in napiergrass $[3,14]$. Roots under litter fertilization had a much higher proportion of biomass in the top $30 \mathrm{~cm}(89 \%)$ than the other treatments (68\%). Root biomass in the top $15 \mathrm{~cm}$ of soil was significantly lower in the inorganic treatment than in the litter or control treatments. However, the proportion of root biomass at the $15-30 \mathrm{~cm}$ depth was significantly higher in the inorganic treatment compared to the control and numerically higher litter treatment (Table 5). Previous research indicated that poultry litter provided elevated soil ammonium and nitrate concentrations in a Tifton loamy sand for 21-28 days after application compared to unamended soil [15]. The observed differences in root distribution throughout the

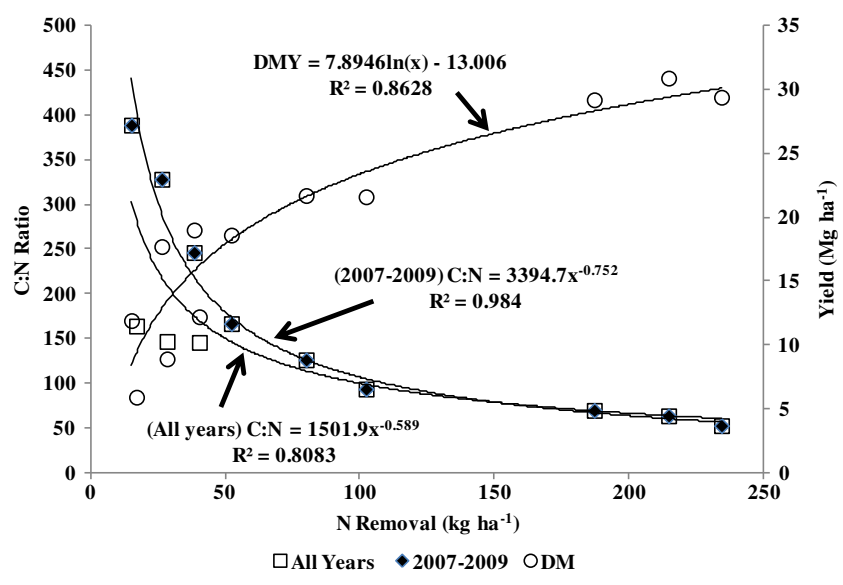

Fig. 2 Relationship between annual mean napiergrass dry matter yield, net nitrogen removal, and $\mathrm{C} / \mathrm{N}$ ratio (2007-2010) profile suggest that under $\mathrm{N}$ deficit conditions, napiergrass can respond to differences in $\mathrm{N}$ distribution by varying root biomass at depth. Thus, the plants growing in litter treated plots concentrated root biomass in the top $30 \mathrm{~cm}$ to take advantage of the slow $\mathrm{N}$ release, while those in the control and inorganic treated plots allocated more resources to explore deeper in the profile.

Root biomass was also collected in April of 2009, and the proportional distribution of roots by depth in September 2010 was used to estimate total root biomass and root turnover during the winter period of senescence. Root DMY estimates totaled 1,300-4,390 $\mathrm{kg} \mathrm{ha}^{-1}$, which ranged from $6 \%$ to $40 \%$ of the total plant biomass, based on the harvest from the previous season (Table 6). These values cover a much greater range, and the control treatment values are lower than previously reported by Knoll et al. [3] for unfertilized napiergrass in spring $\left(3,680 \mathrm{~kg} \mathrm{ha}^{-1}\right.$ DMY; $24.3 \%$ of total biomass). Total root biomass was $14 \%$ $31 \%$ greater under the litter treatment during active growth and $67 \%-129 \%$ less immediately following senescence than in the control or inorganic treatments, respectively (Table 6). While this difference was significant only in 2009 between the litter and inorganic treatments, the difference on total root biomass between April 2009 and September 2010 was substantially greater under the litter treatment than the other two treatments and the difference between years was significant only under the litter treatment (Table 6). The difference between seasons provides an estimate of potential root turnover (decomposition) during winter senescence and suggests a possible mechanism by which napiergrass responds to differences in nutrient availability and presentation.

Total root biomass was $13 \%, 79 \%$, and $239 \%$ greater during active growth than during winter senescence for the inorganic, control, and litter treatments, respectively (Table 6). While the difference in root biomass between sampling dates was significant only for the litter treatment, the differences in the proportion of root biomass to above-ground biomass between the two sampling dates was significant in all three treatments and the inorganic treatment demonstrated the smallest change in root/shoot ratio between sampling dates (9.4\% versus $27.4 \%$ and $29.2 \%$ for the litter and control treatments). When considered in context that the spring litter treatment root biomass was significantly lower than that of the inorganic treatment and there was no difference in fall root biomass among treatments, we suggest that napiergrass may be able to regulate fine root turnover near the soil surface (litter and control treatments) versus maintaining living root biomass throughout the senescent period (inorganic treatments) in response to $\mathrm{N}$ availability. Based on the $\mathrm{C}$ and $\mathrm{N}$ concentrations measured in these roots, $440-690 \mathrm{~kg} \mathrm{ha}^{-1} \mathrm{C}$ and $8-14 \mathrm{~kg} \mathrm{ha}^{-1} \mathrm{~N}$ was stored in the roots during senescence and $1,160-1,900 \mathrm{~kg} \mathrm{ha}^{-1} \mathrm{C}$ and $14-23 \mathrm{~kg} \mathrm{ha}^{-1} \mathrm{~N}$ during active 
Table 5 Napiergrass root profile in September $2010^{\mathrm{a}}$

\begin{tabular}{|c|c|c|c|c|c|c|c|c|c|c|c|c|}
\hline \multirow[t]{2}{*}{ Depth $(\mathrm{cm})$} & \multicolumn{4}{|c|}{ Inorganic } & \multicolumn{4}{|l|}{ Litter } & \multicolumn{4}{|l|}{ Control } \\
\hline & $\mathrm{kg} \mathrm{ha}^{-1}$ & $\mathrm{SE}^{\mathrm{b}}$ & $\%^{\mathrm{c}}$ & SE & $\mathrm{kg} \mathrm{ha}^{-1}$ & SE & $\%$ & SE & $\mathrm{kg} \mathrm{ha}^{-1}$ & $\mathrm{SE}$ & $\%$ & SE \\
\hline $0-15$ & $1,400 \mathrm{a}$ & 100 & $54.7 \mathrm{a}$ & 9.0 & $3,450 \mathrm{~b}$ & 1,090 & $78.8 \mathrm{~b}$ & 0.4 & $1,650 \mathrm{~b}$ & 30 & $59.0 \mathrm{ab}$ & 12.0 \\
\hline $15-30$ & $340 \mathrm{a}$ & 380 & $13.4 \mathrm{a}$ & 17.9 & $550 \mathrm{ab}$ & 520 & $10.3 \mathrm{ab}$ & 21.1 & $260 \mathrm{~b}$ & 440 & $9.2 \mathrm{~b}$ & 21.6 \\
\hline $30-45$ & $130 \mathrm{a}$ & 410 & $4.9 \mathrm{a}$ & 15.5 & $140 \mathrm{a}$ & 840 & $4.0 \mathrm{a}$ & 23.4 & $90 \mathrm{a}$ & 440 & $3.2 \mathrm{a}$ & 20.3 \\
\hline $45-60$ & $110 \mathrm{a}$ & 30 & $4.6 \mathrm{a}$ & 3.1 & $110 \mathrm{a}$ & 310 & $2.4 \mathrm{a}$ & 3.9 & $180 \mathrm{a}$ & 30 & $5.9 \mathrm{a}$ & 1.8 \\
\hline $60-75$ & $640 \mathrm{a}$ & 90 & $19.4 \mathrm{a}$ & 5.0 & $60 \mathrm{a}$ & 110 & $1.9 \mathrm{a}$ & 3.1 & $80 a$ & 60 & $2.8 \mathrm{a}$ & 3.2 \\
\hline $75-90$ & $1,090 \mathrm{ab}$ & 70 & $2.9 \mathrm{a}$ & 2.5 & $80 \mathrm{~b}$ & 90 & $2.6 \mathrm{a}$ & 2.8 & $1,600 \mathrm{a}$ & 40 & $20.0 \mathrm{a}$ & 2.1 \\
\hline
\end{tabular}

${ }^{a}$ Within individual soil depths, root mass or \% root distribution values with the same letter are not significantly different between treatments $(P \geq 0.10)$

${ }^{\mathrm{b}} S E$ standard error

${ }^{\mathrm{c}}$ Percent of total root biomass in 0-90 $\mathrm{cm}$ profile

growth (Table 6). Differences between $\mathrm{C}$ storage during spring versus fall suggest that the turnover of root biomass during the senescent period may contribute 460,940 , and $1,470 \mathrm{~kg} \mathrm{C} \mathrm{ha}^{-1}$ to the top meter of soil in the inorganic, control, and litter treatments, respectively. Difference data also suggests that the turnover of roots under the inorganic and control treatments contribute little to no $\mathrm{N}$ to the soil pool while those under the litter treatment may help retain as much as $15 \mathrm{~kg} \mathrm{~N} \mathrm{ha}^{-1}$ year $^{-1}$.

\section{Effects on Soil Properties}

In 2009, after 2 years of napiergrass production, the $\mathrm{pH}$ in the top layer of the soil profile $(0-15 \mathrm{~cm})$ was significantly lower for the inorganically fertilized treatment (5.6) than the litterfertilized treatment (6.2). The $\mathrm{pH}$ of the control soil at the 0 $15 \mathrm{~cm}$ depth was 6.1 ; not significantly different from either fertilized treatment. At deeper layers, the average soil $\mathrm{pH}$ was 5.5, and there were no differences between treatments (data not shown). Soil acidification from inorganic $\mathrm{N}$ fertilizers has been observed in other studies. For example, on three different soils in Kansas, 10 years of chemical $\mathrm{N}$ fertilizer application reduced soil $\mathrm{pH}$ 0.5-0.7 units compared to unfertilized controls at both the 6-14 cm depth and the 21-29 $\mathrm{cm}$ depth [16]. A similar drop in $\mathrm{pH}$ in the $0-15 \mathrm{~cm}$ soil layer was observed after only 2 years in this research, reflecting the lower buffering capacity of the sandier Tifton soil.

Over the course of the experiment, an increase in soil C was observed in all treatments (Table 7), but there were no differences among treatments. Averaged across all treatments, soil C increased $4,260 \mathrm{~kg} \mathrm{ha}^{-1}$ in the $0-15 \mathrm{~cm}$ layer, decreased $1,360 \mathrm{~kg} \mathrm{ha}^{-1}$ in the $30-45 \mathrm{~cm}$ layer, and did not change significantly in the $60-75 \mathrm{~cm}$ layer. The soil $\mathrm{C}$ increase was significant under all treatments in the 0 $15 \mathrm{~cm}$ layer, and the decrease in soil $\mathrm{C}$ in the $30-45 \mathrm{~cm}$ layer was significant only for the inorganic treatment. There were no differences in $\mathrm{C}$ accumulation in the $60-75 \mathrm{~cm}$ soil layer. The combined soil $\mathrm{C}$ accumulation for all three layers over the 4 years of the experiment was 2,510, 3,660, and $3,350 \mathrm{~kg} \mathrm{ha}^{-1}$ for the inorganic, litter, and control

Table 6 Summary of napiergrass root data, sampled in soil cores taken on two different dates ${ }^{\mathrm{a}}$

\begin{tabular}{|c|c|c|c|c|c|}
\hline Sample date & Treatment & $\begin{array}{l}\text { Root DMY } \\
\mathrm{kg} \mathrm{ha}^{-1}( \pm \mathrm{SE})\end{array}$ & Root C & Root N & $\begin{array}{l}\text { DMY in roots } \\
\%\end{array}$ \\
\hline \multirow[t]{3}{*}{ Apr 2009} & Inorganic & $2,970(980) a$ & $690(240) \mathrm{a}$ & $14(4) \mathrm{a}$ & $12.1 \mathrm{a}$ \\
\hline & Litter & $1,300(160) b$ & $440(60) \mathrm{b}$ & $8(1) \mathrm{a}$ & $5.6 \mathrm{~b}$ \\
\hline & Control & $2,160(620) \mathrm{ab}$ & 660 (170)ab & $11(3) \mathrm{a}$ & $10.4 \mathrm{ab}$ \\
\hline \multirow[t]{3}{*}{ Sept 2010} & Inorganic & $3,350(370) a$ & 1,160 (200)a & $14(2) \mathrm{a}$ & $21.5 \mathrm{a}$ \\
\hline & Litter & $4,390(1,410) a$ & $1,900(650) a b$ & $23(6) b$ & $33.0 \mathrm{ab}$ \\
\hline & Control & $3,860(800) a$ & $1,600(340) \mathrm{b}$ & 15 (2)ab & $39.6 b$ \\
\hline \multirow[t]{3}{*}{ Difference } & Inorganic & 380 & 460 & 0 & $9.4^{\mathrm{c}}$ \\
\hline & Litter & $3,090^{\mathrm{c}}$ & $1,470^{\mathrm{c}}$ & $15^{\mathrm{c}}$ & $27.4^{\mathrm{c}}$ \\
\hline & Control & 1,700 & 940 & 4 & $29.2^{\mathrm{c}}$ \\
\hline
\end{tabular}

${ }^{a}$ Within sample dates and columns, means with the same letter are not significantly different $(P \geq 0.10)$

${ }^{\mathrm{b}}$ Percentage of total DMY in roots in relation to either the 2008 harvest (April 2009 sample) or the 2010 harvest (September 2010 sample)

${ }^{\mathrm{c}}$ Difference between 2009 and 2010 was significant $(P \leq 0.05)$ 
Table 7 Total soil carbon pools $\left[\mathrm{kg} \mathrm{ha}^{-1},( \pm \mathrm{SE})\right]$ before napiergrass planting and during the fall and winter of the final harvest season
${ }^{a}$ Within sample date and depth increment, treatment means with the same lowercase letter are not significantly different $(P \geq 0.05)$

${ }^{\mathrm{b}}$ Within treatment and depth increment, means with the same uppercase letter are not significantly different $(P \geq 0.05)$ among sampling dates

\begin{tabular}{|c|c|c|c|}
\hline & 05-Jun-07 & 29-Sept-10 & 29-Mar-11 \\
\hline & & $0-15 \mathrm{~cm}$ & \\
\hline Inorganic & $12,200(400) \mathrm{a}^{\mathrm{a}} \mathrm{A}^{\mathrm{b}}$ & $19,300(1,800) \mathrm{aB}$ & $17,000(1,000) \mathrm{aB}$ \\
\hline Litter & $13,400(600) \mathrm{aA}$ & $29,400(2,800) \mathrm{bB}$ & $16,800(600) \mathrm{aC}$ \\
\hline \multirow[t]{2}{*}{ Control } & $12,200(900) \mathrm{aA}$ & $22,100(4,600)$ abB & $16,700(1,200) \mathrm{aB}$ \\
\hline & & $30-45 \mathrm{~cm}$ & \\
\hline Inorganic & $9,700(1,500) \mathrm{aA}$ & $8,300(1,200) \mathrm{aAB}$ & $7,000(500) \mathrm{aB}$ \\
\hline Litter & $7,600(1,000) \mathrm{aA}$ & $8,500(700) \mathrm{aA}$ & $7,100(500) \mathrm{aA}$ \\
\hline \multirow[t]{2}{*}{ Control } & $7,600(1,400) \mathrm{aA}$ & $6,400(700) \mathrm{aA}$ & $6,700(400) \mathrm{aA}$ \\
\hline & & $60-75 \mathrm{~cm}$ & \\
\hline Inorganic & $3,200(500) \mathrm{aA}$ & $3,700(1,400) \mathrm{aA}$ & $3,700(500)$ aA \\
\hline Litter & $2,500(400) \mathrm{aA}$ & $4,300(600) \mathrm{aB}$ & $3,200(300) \mathrm{aAB}$ \\
\hline \multirow[t]{2}{*}{ Control } & $3,600(600) \mathrm{aA}$ & $3,500(300) \mathrm{aA}$ & $3,300(400)$ aA \\
\hline & & Partial profile & \\
\hline Inorganic & $25,100(1200) \mathrm{aA}$ & $31,300(2,300) \mathrm{aB}$ & $27,600(1,300) \mathrm{aB}$ \\
\hline Litter & $23,400(900) \mathrm{aA}$ & $42,300(1,700) \mathrm{bB}$ & $27,100(600) \mathrm{aC}$ \\
\hline Control & $23,400(1,800) \mathrm{aA}$ & $32,000(5,200)$ abA & $26,800(1,300) \mathrm{aA}$ \\
\hline Depth & & Average, all treatments & \\
\hline $0-15 \mathrm{~cm}$ & $12,600(400) \mathrm{A}$ & $23,600(2,200) \mathrm{B}$ & $16,900(600) \mathrm{C}$ \\
\hline $30-45 \mathrm{~cm}$ & $8,300(700) \mathrm{A}$ & $7,800(600) \mathrm{AB}$ & $6,900(300) \mathrm{B}$ \\
\hline $60-75 \mathrm{~cm}$ & $3,100(300) \mathrm{A}$ & $3,900(500) \mathrm{A}$ & $3,400(200) \mathrm{A}$ \\
\hline
\end{tabular}
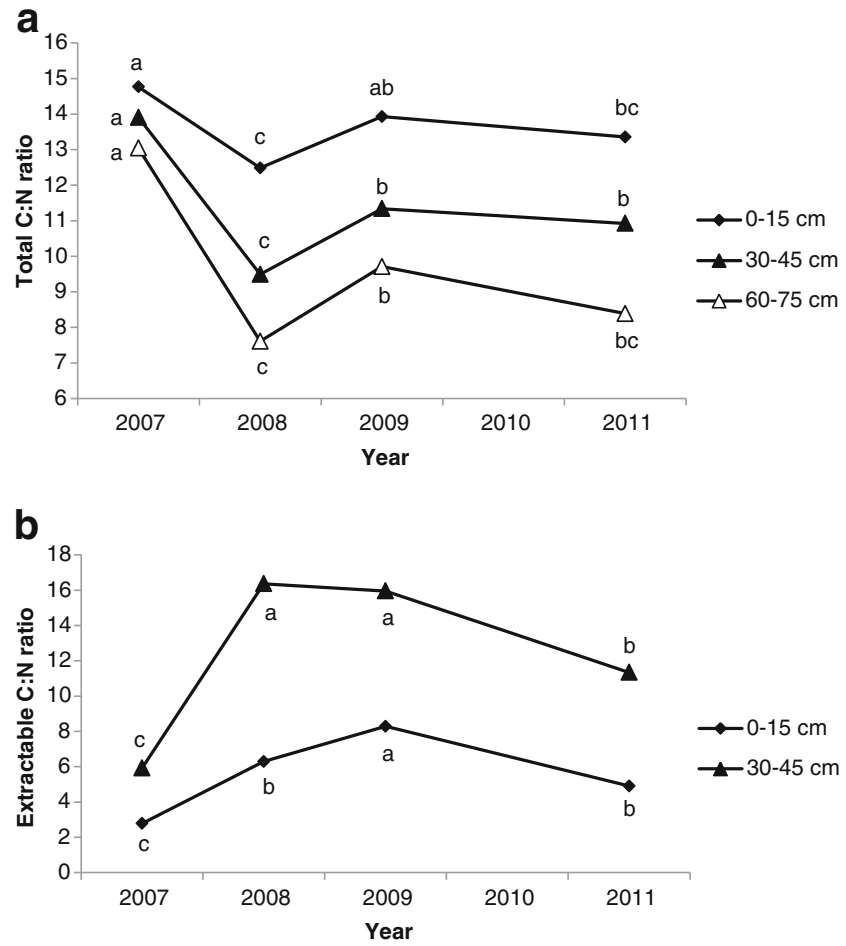

Fig. 3 Soil $\mathrm{C} / \mathrm{N}$ ratios for the total $\mathrm{C}$ and $\mathrm{N}$ (a) or for the extractable $\mathrm{C}$ and $\mathrm{N}$ fractions (b) at varying soil depths in napiergrass plots, sampled from 2007 to 2011 . Within soil layers, means with the same letter are not significantly different $(P \geq 0.05)$ treatments, respectively, and the increases were significant for the inorganic and litter treatments.

The total soil $\mathrm{C} / \mathrm{N}$ ratio showed a slight downward trend from 2007 to 2011 at all three soil layers sampled (0-15, $30-45$, and $60-75 \mathrm{~cm}$; Fig. 3a), but there were no major differences between the fertilizer treatments. In contrast, the ratio of extractable $\mathrm{C} / \mathrm{N}$ showed a general increase in both the $0-15 \mathrm{~cm}$ and $30-45 \mathrm{~cm}$ depths (Fig. 3b). The change in $\mathrm{C} / \mathrm{N}$ ratio in either the total or extractable fractions was greatest from 2007 to 2008, concurrent with the large removal of $\mathrm{N}$ in the biomass in the 2007 growing season. The slopes of the regression lines comparing total $\mathrm{C}$ and total $\mathrm{N}$ do not significantly change across years (data not shown). However, a similar analysis on the extractable fractions of $\mathrm{C}$ and $\mathrm{N}$ from the $0-15 \mathrm{~cm}$ and $30-45 \mathrm{~cm}$ soil layers indicates an accelerating depletion of the $\mathrm{N}$ in this pool over the first 3 years of the research (Fig. 4). The slope of the regression between $\mathrm{C}$ and $\mathrm{N}$ for both 2007 and 2008 are significantly greater than for the other 2 years in both soil layers. These results suggest that the high DMY obtained in the first 2 years was possible due to the mining of available $\mathrm{N}$ stored in labile soil organic matter. Considered together with the observation that total soil $\mathrm{C}$ increased significantly over the 4 years of the project and the total soil $\mathrm{C} / \mathrm{N}$ ratio remained unchanged, it is possible that the $\mathrm{C}$ accumulation observed during the project has peaked for the $\mathrm{N}$ fertilization level examined. 
Fig. 4 Extractable $\mathrm{C}$ versus extractable $\mathrm{N}$ in the $0-15 \mathrm{~cm}$ and $30-45 \mathrm{~cm}$ soil layers of napiergrass plots for sampling dates $(2007,2008,2009$, and 2010). The slope of regressions followed by the same letter are not significantly different $(P \geq 0.05)$
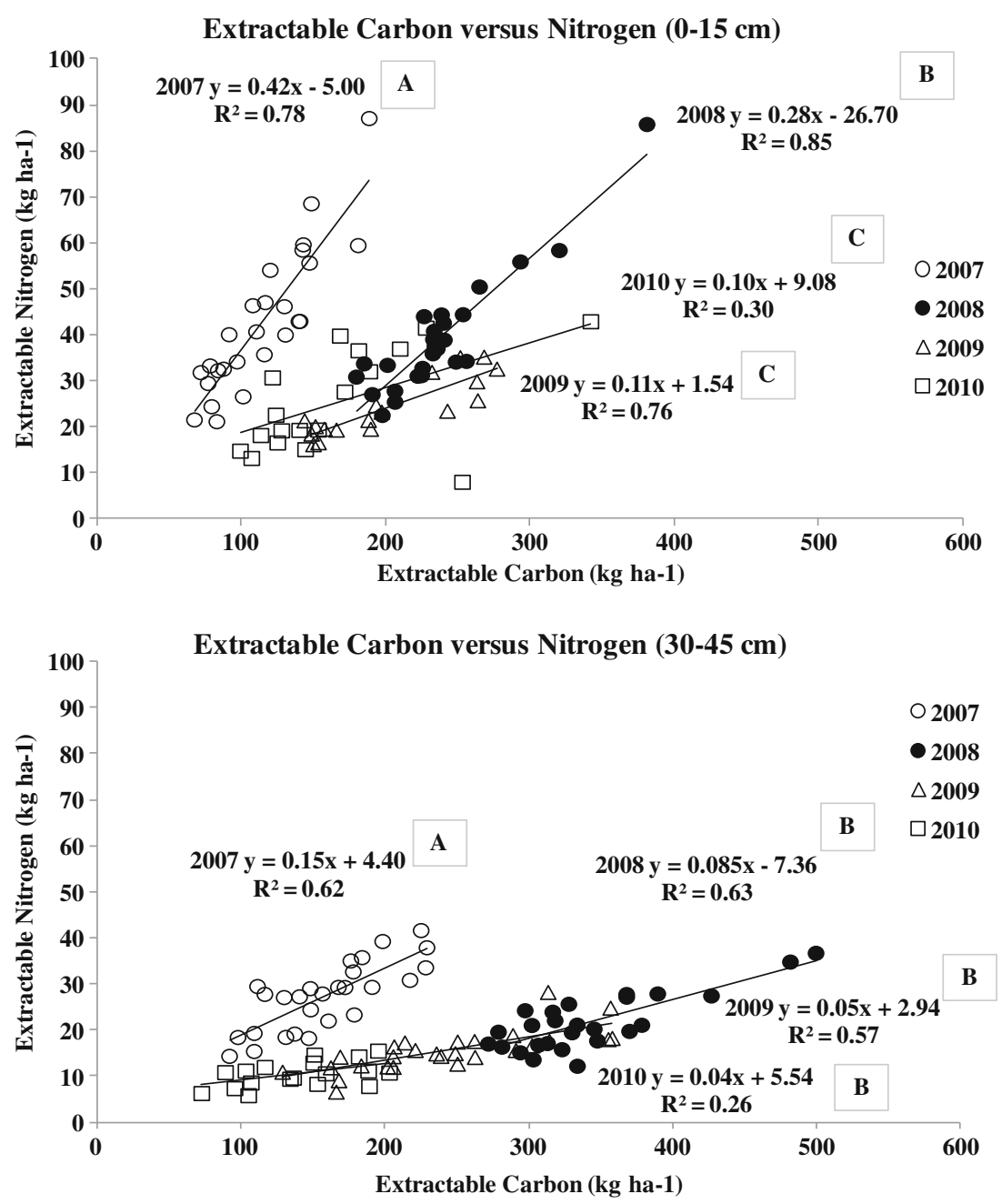

\section{Conclusions}

Fertilization with poultry litter or inorganic fertilizer with equal content of $\mathrm{N}, \mathrm{P}$, and $\mathrm{K}$ resulted in similar DMY that consistently exceeded that of unfertilized control plots. Yields in all treatments declined after 2 years, and this was attributed primarily to $\mathrm{N}$ deficiency at the rate applied $\left(\sim 100 \mathrm{~kg} \mathrm{ha}^{-1}\right.$ year $\left.^{-1}\right)$. Biomass $\mathrm{N}$ concentration and total $\mathrm{N}$ removal in biomass were generally greatest in the inorganically fertilized plots, while biomass $\mathrm{P}$ concentration and $P$ removal were greatest in the plots fertilized with poultry litter. Napiergrass has a high capacity to remove excess $P$ from applied poultry litter, so a higher rate of litter could possibly be applied. However, supplementation with inorganic $\mathrm{N}$ is probably needed in order to achieve maximum yields while minimizing nutrient releases into the environment, and use of poultry litter could help to buffer the soil $\mathrm{pH}$ from acidification caused by the inorganic $\mathrm{N}$ fertilizer. Excessive concentrations of nutrients such as $\mathrm{P}$ and $\mathrm{K}$ in biomass could be undesirable depending on the intended application, for example direct combustion [13], and this must be considered when fertilizing biomass crops. Irrespective of fertilization treatment, production of napiergrass resulted in increases in soil $\mathrm{C}$ pools. Soil $\mathrm{C}$ increased $2,510-3,350 \mathrm{~kg} \mathrm{ha}^{-1}$ over the first 4 years of production suggesting that napiergrass will serve as a $\mathrm{C}$ positive biofuels feedstock. Although there was some accretion of $\mathrm{N}$ in the soil profile, the decrease in the $\mathrm{C} / \mathrm{N}$ ratio of chloroform-extractable organic matter from the soil suggests that much of the accumulated $\mathrm{N}$ is unavailable for plant uptake.

Acknowledgments This research is a contribution of the USDA Southeast Regional Biomass Research Center, the USDA ARS Gulf Atlantic Coastal Plain Long-Term Agro-ecosystem Research site, and the USDA-ARS GRACEnet Project. Dr. Malik's contributions were supported in part by a fellowship from the Consortium for Plant Biotechnology Research, Inc. through a grant from the U.S. Department of Energy (Agreement DE-FG36-02GO12026). The authors would like to thank Freddie Cheek, Tony Howell, Lorine Lewis, Bobby Shiver, Coby Smith, Andrew Stinson, and DeeAnne Webb for technical assistance in the field and laboratory. 
Open Access This article is distributed under the terms of the Creative Commons Attribution License which permits any use, distribution, and reproduction in any medium, provided the original author(s) and the source are credited.

\section{References}

1. Calhoun DS, Prine GM (1985) Response of elephantgrass to harvest interval and method of fertilization in the colder subtropics. Soil Crop Sci Soc Fla Proc 44:111-115

2. Castillo MS, Sollenberger LE, Vendramini JMB, Woodard KR, O'Connor GA, Newman YC, Silveira ML, Sartain JB (2010) Municipal biosolids as an alternative nutrient source for bioenergy crops: I. Elephantgrass biomass production and soil responses. Agron J 102:1308-1313

3. Knoll JE, Anderson WF, Strickland TC, Hubbard RK, Malik R (2012) Low-input production of biomass from perennial grasses in the Coastal Plain of Georgia USA. Bioenerg Res 5:206-214

4. Gascho GJ, Hubbard RK (2006) Long-term impact of broiler litter on chemical properties of a Coastal Plain soil. J Soil Water Conserv 61(2):65-74

5. Adeli A, Shankle MW, Tewolde H, Sistani KR, Rowe DE (2008) Nutrient dynamics from broiler litter applied to no-till cotton in an upland soil. Agron J 100:564-570

6. Sainju UM, Senwo ZN, Nyakatawa EZ, Tazisong IA, Reddy KC (2008) Soil carbon and nitrogen sequestration as affected by longterm tillage, cropping systems, and nitrogen fertilizer sources. Agric Ecosystems Environ 127:234-240

7. Fisher MJ, Rao IM, Ayarza MA, Lascano CE, Sanz JI, Thomas RJ, Vera RR (1994) Carbon storage by introduced deep-rooted grasses in the South American savannas. Nature 371:236-238

8. Carter MR, Gregorich EG (2010) Carbon and nitrogen storage by deep-rooted tall fescue (Lolium arundinaceum) in the surface and subsurface soil of a fine sandy loam in eastern Canada. Agric Ecosyst Environ 136:125-132

9. Garten CT Jr, Smith JL, Tyler DD, Amonette JE, Bailey VL, Brice DJ, Castro HF, Graham RL, Gunderson CA, Izaurralde RC, Jardine PM, Jastrow JD, Kerley MK, Matamala R, Mayes MA, Metting FB, Miller RM, Moran KK, Post WM, Sands RD, Schadt CW, Phillips JR, Thomson AM, Vugteveen T, West TO, Wullschleger SD (2010) Intra-annual changes in biomass, carbon, and nitrogen dynamics at 4-year old switchgrass field trials in west Tennessee USA. Agric Ecosyst Environ 136:177184

10. U.S. Government Printing Office (GPO). 2007. Energy Independence and Security Act. Public Law 110-140. 310 pp.

11. Burton GW (1989) Registration of 'Merkeron' napiergrass. Crop Sci 29:1327

12. Burvall J (1997) Influence of harvest time and soil type on fuel quality in reed canary grass (Phalaris arundinacea L.). Biomass Bioenergy 12:149-154

13. Lewandowski I, Clifton-Brown JC, Andersson B, Basch G, Christian DG, Jørgensen U, Jones MB, Riche AB, Schwarz KU, Tayebi K, Teixeira F (2003) Environment and harvest time affects the combustion qualities of Miscanthus genotypes. Agron J 95:1274-1280

14. Woodard KR, Prine GM (1993) Dry-matter accumulation of elephantgrass, energycane, and elephant millet in a subtropical climate. Crop Sci 33:818-824

15. Hubbard RK, Bosch DD, Marshall LK, Strickland TC, Rowland D, Griffin TS, Honeycutt CW, Albrecht SL, Sistani KR, Torbert HA, Wienhold BJ, Woodbury BL, Powell JM (2008) Nitrogen mineralization from broiler litter applied to southeastern Coastal Plain soils. J Soil Water Conserv 63(4):182-192

16. Intrawech A, Stone LR, Ellis R Jr, Whitney DA (1982) Influence of fertilizer nitrogen source on soil physical and chemical properties. Soil Sci Soc Am J 46:832-836 